\title{
CONSTRUCTION OF INTELLIGENT CAMPUS TENNIS \\ PLAYERS' BODY DATA MONITORING AND INJURY WARNING SYSTEM BASED ON DATA FUSION
}

\author{
CONSTRUÇÃO DE SISTEMA INTELIGENTEDE MONITORAMENTO DE DADOS CORPORAIS EALERTADE \\ LESÕES PARA JOGADORES DE TÊNIS BASEADO NA FUSÃO DEDADOS \\ CONSTRUCCIÓN DE UN SISTEMA INTELIGENTE DEMONITOREO DE DATOS FÍSICOS Y ALERTA TEMPRANA
DE LESIONES PARA JUGADORES DE TENIS DEL CAMPUS BASADO EN LA FUSIÓN DE DATOS
}

Yan Li' (D)

(Public Health Education)

1. Guilin University of Aerospace Technology, Guilin, Guangxi, China.

\section{Correspondence:}

Guilin, Guangxi, China.

kv187zavw4486@126.com

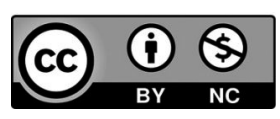

\begin{abstract}
As far as competitive sports are concerned, scientifically organizing the training process and strictly following the training rules are the only way to success. Tennis is the foundation of all sports. It develops physical and motor skills in a comprehensive and effective manner. Biomechanical diagnosis is mainly carried out on the basis of force-time curve recording of different movement modes, and the generated data is processed by computer through a special measuring device. The main purpose of this study is to use data fusion technology to analyze and evaluate the injury factors involved in various sports. Based on this, a dynamic chain model for early warning of sports injury risk factors is established, which can provide a reference for athletes to avoid and reduce the risk of injuries and ensure normal training and competition. In tennis training, scientific training monitoring is applied to diagnose and monitor athletes' physical function and psychological state. Conduct humanized and scientific management of the training process.
\end{abstract}

Keywords: Tennis; Data Aggregation; Damage Assessment Scientific Training.

\section{RESUMO}

No que se refere aos esportes competitivos, a organização científica do processo de treinamento e o cumprimento estrito das regras de treinamento são a única forma de êxito. O tênis é a base de todos os esportes. O tênis desenvolve competências físicas e motoras de uma forma abrangente e eficaz. O diagnóstico biomecânico é realizado principalmente com base na gravação da curva força-tempo de diferentes modos de movimento, e os dados gerados são processados pelo computador através de um dispositivo de medição especial. O objetivo principal deste estudo é usar a tecnologia de fusão de dados para analisar e avaliar vários fatores de lesão esportiva. Com base nisso, estabelece-se um modelo dinâmico de cadeia para o alerta precoce de fatores de risco de lesão esportiva, podendo fornecer uma referência para que os atletas evitem e reduzam o risco de lesão e garantam a normalidade dos treinos e das competições. No treinamento de tênis, aplica-se o monitoramento de treinamento científico para diagnosticar e monitorar a função física dos atletas e seu estado psicológico. Conduzir a gestão humanizada e científica do processo de treinamento.

Descritores: Tênis; Agregação de Dados; Avaliação de Danos Treino Científico.

\section{RESUMEN}

En lo que se refiere a los deportes competitivos, la organización científica del proceso de entrenamiento y el cumplimiento estricto de las reglas de entrenamiento son la única forma de éxito. El tenis es la base de todos los deportes. El tenis desarrolla competencias físicas y motoras de una forma abarcadora y eficaz. El diagnóstico biomecánico es realizado principalmente basándose en la grabación de la curva fuerza-tiempo de diferentes modos de movimiento, y los datos generados son procesados por la computadora por medio de un dispositivo de medición especial. El objetivo principal de este estudio es usar la tecnología de fusión de datos para analizar y evaluar varios factores de lesión deportiva. Sobre esa base, se establece un modelo dinámico de cadena para la alerta precoz de factores de riesgo de lesión deportiva, pudiendo proveer una referencia para que los atletas eviten y reduzcan el riesgo de lesión y garanticen la normalidad de los entrenamientos y de las competencias. En el entrenamiento de tenis, se aplica el monitoreo de entrenamiento científico para diagnosticary monitorear la función física de los atletas y su estado psicológico. Conducir la gestión humanizada y científica del proceso de entrenamiento.

Descriptores: Tenis; Agregación de Datos; Evaluación de Daños Entrenamiento Científico. 


\section{INTRODUCTION}

As far as competitive sports is concerned, the only way to succeed is to organize the training process scientifically and strictly follow the training rules. ${ }^{1}$ At present, in high-level sports teams, many coaches face the most serious problem: athletes who can win gold have injury problems, while athletes who can participate in competitions do not have the strength to win gold. Sports training, especially strength training, can make muscle fibers thicker, "have inherent tension stronger, and increase the muscle quality. ${ }^{2}$ Improvement of coordination between muscle groups and muscles, changes in the adaptability of muscle fiber types, and enhanced connective tissue elasticity can effectively increase muscle strength. ${ }^{3}$ Tennis is known as the mother of sports and the basis of all sports. It can comprehensively and effectively develop people's physical fitness and sports skills and play a very good role in developing other sports technology and the improvement of sports achievements. ${ }^{4}$ In recent years, athletes have a long training time and a large body load, which has led to an increase in the incidence of injury. Seriously hindering athletes to maintain and further improve their athletic performance, and even lead athletes to leave the game too early. Exercise stimulation can cause changes in cardiovascular, endocrine, immune, skeletal muscle, oxygen transport and utilization, material energy metabolism and metabolic capacity.

Excessive training load not only cannot improve exercise capacity but will appear excessive training. Therefore, in sports training, scientific and rational use of medical testing techniques and biochemical indicators to assess athletes' functional status. To carry out more scientific training, the physical function state of track and Tennis players should be correctly and objectively recognized, and biochemical indicators such as endocrine system, oxygen transport system, bone material energy metabolism system and immune system should be detected. Correctly evaluate the athlete's physical state to better deal with the relationship between exercise load and recovery. Find the best amount of training and restore balance points. Based on data fusion technology, this paper carries out an experimental study on the influence of the combination of different training methods on human muscle strength characteristics. Through the analysis of the experimental results, the effect and significance of different combination exercises are explored. The treatment and prevention of sports injury have always been the focus of attention in sports medicine. Studies have shown that sports injuries are not caused by a simple reason but they are often the result of a combination of multiple factors. It is very important for controlling training load, judging sports fatigue, reasonable nutrition supplement and predicting sports performance.

\section{RELATED WORK}

At the beginning of this century, functional training gradually entered the vision of competitive sports workers. These training methods have been paid more and more attention by training experts and coaches and become the best supplement to physical training methods, which bring great help to athletes. So the foreign experts are more and more interested in functional training, and the research is more and more in-depth. Michael Boyle believes that physical functional training is that athletes can control the stability of the body, and at the same time, take their own weight as the load to do various movement exercises in multi-plane. Gambetta believes that athletes' functional training mainly includes three aspects of body acceleration, transmission and stability. In functional training, the forces involved are mainly complex movements in multiple planes. It emphasizes the efficient transfer of forces between multiple joints, where the nervous system and muscle mass perception play a crucial role in this process. Vern pointed out in the study that exercise training should follow the integrity of the human physiological structure.
The body's movement system is a unified whole under natural conditions. The muscles bind the bones together in a mechanical structure like a rope to form a complete system. Thomaskurz also pointed out that, unlike traditional physical training, functional training pays more attention to the training of the whole body muscle. Through the training of action patterns based on functional anatomy, athletes can help them establish correct, stable and efficient action patterns, thus helping athletes to reduce the risk of sports injuries. Charles Staley emphasizes the stability of movement in his functional training. With the help of various instruments, create a dynamic and unstable movement environment. Thus, the difficulty of movement is increased, so that athletes'small muscle group and deep stable muscle group can get more training.

\section{EXPERIMENTAL ANALYSIS AND DISCUSSION}

Low-level athletes with short training years, although they have not fully mastered the correct movement techniques, but they have shorter training time, the action mode before training is more correct, and no movement deformation occurs. The force-measuring platform can compensate for the defect that only a single joint muscle group can be tested in the isokinetic test system, and can comprehensively reflect the dynamics of the entire bounce process. The first step in training monitoring is to build a model that includes a norm, a good model, and a target model. Then, the indicators of different models are established, and the collected indicators of the athletes are compared with the models, and the training plan is adjusted. This is a cyclic process to achieve effective control of training. Moderate exercise generally does not affect the plasma testosterone concentration, but after strength training, the plasma testosterone level tends to rise, but a large amount of exercise over a long period of time will also lead to a decrease in the plasma testosterone concentration. In the whole process of the development of human movement mode, if one of the links has problems, it will lead to obvious movement restriction or dysfunction. Therefore, these basic modes of action are the basis of higher skills. Only the correct action mode can produce the correct action technology. On the contrary, correct movement skills can also help athletes learn the correct movement patterns. Statistical results of various mechanical indexes before and after training are given. The experimental results are shown in Figure 1.

All subjects had the same training time, the same training group and the same exercise load. In order to control the influence of teachers teaching experience on the experimental subjects, the same teacher was responsible for the technical teaching and strength training of the two groups during the experiment. When formulating the training monitoring

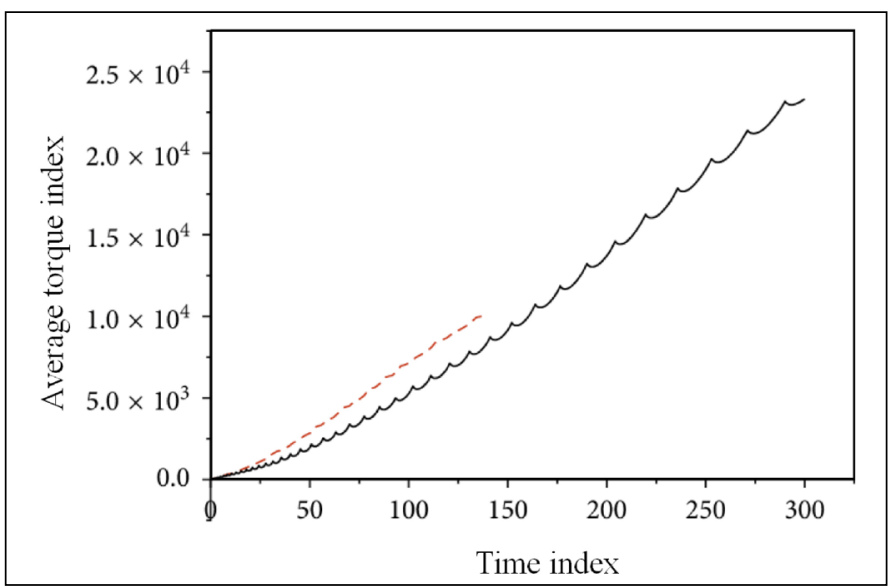

Figure 1. Comparison of average muscle strength of knee extension before and after training. 
program, we should formulate a feasible monitoring program according to the coaches future training arrangements. To understand the training plan, training content and training purpose of coaches throughout the year. In the judgment process, the plasma testosterone concentration varies with individual differences. Only one measurement is made, and comparison with normal people is obviously not comprehensive enough, and vertical comparison is practical.

In the traditional physical training, the coaches often pay attention to the number of exercises and the intensity of training, but ignore the hidden dangers of the athletes themselves. The myoelectric spectrum of the damage warning system is digitized. In the analysis of the spectrum, the change in the center frequency can be used as a quantitative indicator for the analysis of fatigue in isometric contraction. The time and space indicators of a gait cycle in the running acceleration phase and the maximum speed phase are shown in Table 1. The time indicators of the ground reaction force in the acceleration phase and the maximum speed phase are shown in Table 2. The braking force and propulsive force change with time as shown in Figure 2.

Because these hidden dangers were not discovered in time, the parts of these hidden dangers caused substantial damage due to the high number and intensity of exercises. Here, using graphs to represent the typical correlation between body shape and physical quality, it is possible to express the typical related logical relationships more intuitively and clearly. Exercise plays a decisive role in our daily life. The effect of exercise on bone is also obvious. The stress stimulation of bone during exercise is especially obvious for bone health.

Table 1. Time and space indicators for a gait cycle in the acceleration phase and the maximum speed phase.

\begin{tabular}{c|c|c|c}
\hline & Acceleration phase & Maximum speed phase & Difference \\
\hline Step size $(\mathrm{m})$ & 4.01 & 4.47 & 0.46 \\
\hline Step frequency & 2.03 & 2.09 & 0.06 \\
\hline Running speed $(\mathrm{m} / \mathrm{s})$ & 7.69 & 9.46 & 1.77 \\
\hline Gait cycle duration $(\mathrm{s})$ & 0.49 & 0.47 & -0.02 \\
\hline
\end{tabular}

Table 2. Time indicators of ground reaction forces during the acceleration phase and the maximum speed phase.

\begin{tabular}{c|c|c|c}
\hline Variable & Acceleration phase & $\begin{array}{c}\text { Maximum } \\
\text { speed phase }\end{array}$ & Difference value \\
\hline Braking force peak & 11.56 & 17.53 & 5.97 \\
\hline Propulsion peak & 69.56 & 82.79 & 13.23 \\
\hline Braking period & 23.64 & 31.48 & 7.84 \\
\hline $\begin{array}{c}\text { Length of promotion } \\
\text { period }\end{array}$ & 42.66 & 53.75 & 11.09 \\
\hline
\end{tabular}

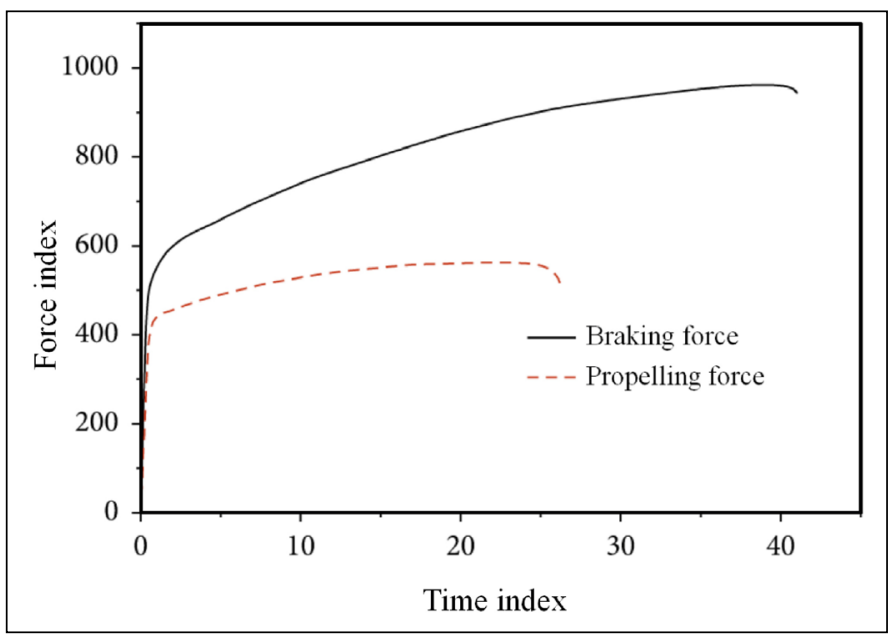

Figure 2. Braking force and propulsive force change with time.
$\mathrm{N}$ represents the generalized coordinate array of the system. The general form is written as:

$$
N\left(\mu, \sigma_{j}^{2}\right)=\frac{1}{(2 \pi)^{1 / 2} \sigma_{j}} e^{\frac{1}{2 \sigma_{j}^{2}}(x-\mu)^{2}}
$$

In the formula, $\mathrm{n}$ represents the generalized velocity array. $\mathrm{H}$ represents the differential equation of system dynamics. F represents an array of algebraic equations describing constraints. If the state vector of the system is defined:

$$
p_{u}(f)=C \sum_{i=1}^{n} K\left(\left\|\frac{f-z_{i}}{h}\right\|^{2}\right) \delta\left[b\left(z_{i}\right)-u\right]
$$

$$
B H(p, q)=\sum_{u=1}^{n} \sqrt{p_{u}(f) q_{u}}
$$

Then the formula can be written as a single matrix equation:

$$
e_{j}=-k \sum_{i=1}^{m}\left(p_{i j} \ln p_{i j}\right)
$$

Compensation will occur when the body posture is incorrect and the muscle strength is not in harmony. Once this happens, athletes are very vulnerable to sports injury. Therefore, the functional movement screening test is designed to evaluate the quality of athletes movements. The contribution of each joint's work to the lower limb's work increases with the additional load. The contribution does not increase or decrease linearly with the increase of load. As shown in Figure 3.

During the teaching and training process, the experimental group and the control group were strictly controlled, and as far as possible, the two groups were compared under the same conditions. In the experiment, the intensity of each exercise, the time, the number of times, the number of groups, etc., are as consistent as possible. In general, exercise within half an hour, blood urea changes are small, only in the case of large-intensity long-term exercise, blood urea changes are obvious. Plasma testosterone and plasma cortisol are biochemical indicators of endocrine system, and plasma testosterone is the main anabolic metabolic hormone in human body. It can not only maintain male sexual function and side-sexual characteristics, but also promote bone growth and secrete erythropoietin, thereby enhancing male aggression awareness. The length of training years can reflect the correctness of athletes movement patterns, and the athletes with longer training years. Through long-term technical training, we can correct the mistakes of the movement mode and help athletes to establish the correct movement mode.

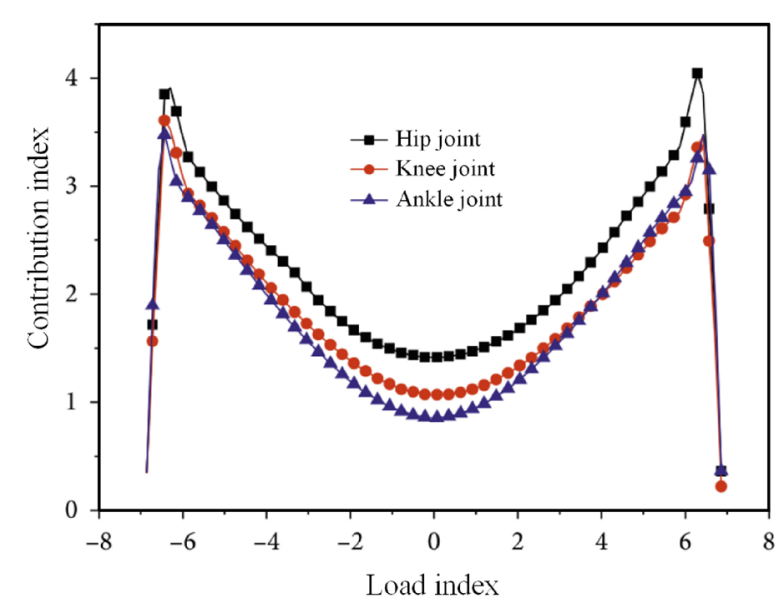

Figure 3. Three joint contribution and load weight data. 


\section{CONCLUSIONS}

The vast majority of sports injuries can be prevented. Although some of them are difficult to prevent from accidental acute injuries, they can still reduce the risk of injury through corresponding preventive measures. This paper combines data fusion technology to screen athletes for functional movements. The training methods designed can improve the subjects'kinematics and kinematics indexes in varying degrees. It shows that the design method conforms to the characteristics of fast force. However, after training in different ways, according to the dynamics and kinematics indicators to analyze, the range of improvement is different. It shows that several training methods have specific effects on different components of fast strength. The plasma testosterone index in the endocrine system, hemoglobin in the oxygen system, and urinary nitrogen and CK in the skeletal muscle and material energy metabolism system are all biochemical indicators for detecting and assessing the physical function of Tennis sports athletes. Training monitoring and early warning have become an indispensable part of the training process. Especially in Tennis sports training, scientific training and monitoring will be used, and the athletes' physical function, technical level and mental state will be diagnosed and monitored. Realize the humanization, dynamic and scientific management of the training process.

\section{ACKNOWLEDGEMENTS}

The study was supported by the Research project of undergraduate teaching reform of Guilin university of aerospace technology in 2019 "Research on the influence of balance training on the hitting stability of college students in tennis elective course" (No.: 2019jb35).

The author declare no potential conflict of interest related to this article

AUTHORS' CONTRIBUTIONS: The author has completed the writing of the article or the critical review of its knowledge content. This paper can be used as the final draft of the manuscript. Every author has made an important contribution to this manuscript. Yan Li: writing and execution.

\section{REFERENCES}

1. Fuchs PM. Diagnosis in track and field performances past the 1988 Ben Johnson doping scandal. Mathematical Methods in the Applied Sciences. 2015;22(15):1351-1373.

2. Tota $Ł$, Maciejczyk M, Pokora I, Cempla J, Pilch W, Pałka T. Changes in endurance performance in young athletes during two training seasons. J Hum Kinet. 2015;49:149-58.

3. Nattiv A, Kennedy G, Barrack MT, Abdelkerim A, Goolsby MA, Arends JC, et al. Correlation of MRI grading of bone stress injuries with clinical risk factors and return to play: a 5-year prospective study in collegiate track and field athletes. Am J Sports Med. 2013;41(8):1930-41

4. Dijkstra HP, Pollock N, Chakraverty R, Alonso JM. Managing the health of the elite athlete: a new integrated performance health management and coaching model. $\mathrm{Br} J$ Sports Med. 2014;48(7):523-31

5. Swenson DM, Collins CL, Fields SK, Comstock RD. Epidemiology of U.S. high school sports-related ligamentous ankle injuries, 2005/06-2010/11. Clin J Sport Med. 2013;23(3):190-6. 